\title{
LEAN CONSTRUCTION PRINCIPLES AND RAILWAY MAINTENANCE PLANNING
}

\author{
Daria Ivina $^{1}$ and Nils O.E. Olsson ${ }^{2}$
}

\begin{abstract}
Lean construction principles have been successfully adopted in a variety of industries to increase project management quality. This paper addresses maintenance planning in Sweden and analyses its effectiveness in the framework of lean construction principles. To investigate the status and improvement potential of maintenance contractors' performance, the study focuses on the detailed planning process, which is mainly the responsibility of contractors. A literature review, a data analysis and interviews were used to reveal the possible barriers to the adaptation of lean principles to the maintenance industry. The study presents a developed theoretical framework for the analysing maintenance processes in the perspective of lean construction principles. We found that the application of lean principles has the potential for improvements in the planning process, but there are some barriers to effective implementation, including a lack of knowledge about lean principles at contractors' sites.
\end{abstract}

\section{KEYWORDS}

Lean construction, railway maintenance, Last Planner ${ }^{\circledR}$ System, workflow, planning

\section{INTRODUCTION}

The importance of maintaining and developing the railway transportation system is obvious, due to its relatively low environmental impact and potential as an efficient transportation system for modern society. A constant increase in the number of trains operating on existing railway infrastructure in Sweden has led to its deterioration. It follows that railway infrastructure maintenance amounts to more than $40 \%$ of expenditures in the railway sector (Liden 2016, Trafikverket 2018).

The Swedish Transport Administration (Trafikverket) is the national infrastructure manager, responsible for the construction, operation and maintenance of Swedish railways (Trafikverket 2019). Maintenance in Sweden is performed by contractors on behalf of Trafikverket. All activities that require secure access to the railway infrastructure must obtain a (work) possession, which guarantees that no trains will run in the designated area during track work performance (RailNetEurope 2017). The application for possessions has to be done in relation to the timetabling and capacity allocation processes. This means that the planning is not primarily based on when the

1 PhD Student, Faculty of Engineering, LTH, Department of Technology and Society, Lund University, Transport and Roads, Box 118, 22100 Lund, Sweden, daria.ivina@tft.lth.se, orcid.org/0000-00020893-4129

2 Professor, Faculty of Engineering, Department of Mechanical and Industrial Engineering, Norwegian University of Science and Technology, 7491 Trondheim, Norway, nils.olsson@,ntnu.no, orcid.org/0000-0002-1344-8555 
necessary information is available. In fact, contractors must apply for the possessions far in advance before the actual scope of work is known, which is an issue regarding a level of predictability for the upcoming operational needs. Liden (2018) defined the planning for possessions at contractors as a "core tactical planning problem for all railway systems." The number of issues referred to the planning process, such as work timing and team or resource scheduling demands greater foresight and structured implementation. Therefore, the purpose of the current research i to study maintenance planning processes based on the Last Planner ${ }^{\circledR}$ framework. While the empirical material is from Sweden, several studies indicate that the challenges in railway maintenance are similar in other countries (Zoeteman 2006, Forsgren et al. 2013, Nikitinas and Dailydka 2016), as well as other industries (Globerson and Zwikael 2002, Heravi et al. 2015).

\section{THEORY}

\section{LEAN PRINCIPLES}

Lean principles are widely used in a range of industries. Literature has shown the positive effects of the introduction of lean principles on customer satisfaction and operational efficiency (Porwal et al. 2010). Lean contains five main principles used to gain maximum benefit from the system (Aziz and Hafez 2013): (1) Specify a value for the customer, (2) Identify value stream, (3) Flow, (4) Pull and (5) Perfection. The main benefit of implementing lean principles is optimisation of processes by eliminating waste (Parry and Turner 2006).

Lean construction is an adapted version of lean production philosophy for the construction industry. Koskela (1999) criticized the traditional conceptual basis of construction and recommended that the construction industry adopt the lean philosophy. One of the major contributions to lean construction from lean production was the concept of Transformation-Flow-Value (TFV) generation (Wolbers et al. 2005).

There are several tools and techniques used in lean construction, such as Last Planner ${ }^{\circledR}$ System (LPS), first run studies, 5S, and fail-safe for quality and safety (Salem et al. 2005). More recent developments include Takt time planning. We chose to focus on LPS because it appears as a suitable framework for analysing the stepwise planning that is a key characteristic of railway maintenance. Oluwatosin et al. (2019) found that LSP is the most widely implemented lean tool in the construction industry.

There are some examples of lean principles within the rail industry. Radnor (2006) argued that lean construction could be successful in the public sector but required adaptation. Zwas (2006) investigated how lean techniques could be employed in the Chicago Transit Authority. Koerckell and Ballard (2005) illustrated the implementation of lean construction in a railway investment project. Last, Dirnberger and Barkan (2007) described the direct waste in the railway industry as unnecessary moves, mistakes that require an operation to be repeated, inadequate track maintenance and unsafe operations.

\section{Last Planner ${ }^{\circledR}$ System}

Based on lean production principles, LPS was developed by Ballard (2000) to make planning processes and workflows reliable and to build trust within a collaborative team environment. Among other principles, in LPS decisions are made as late as possible by the person who knows the most about the specific task. In this way, the team works more concurrently and everyone gains an understanding of the value chain (Koskela 1999). 
Currently, there are four established metrics to measure LPS implementation effectiveness (Ballard and Tommelein 2016): Percentage Plan Completed (PPC), Tasks Made Ready, Tasks Anticipated, and Frequency of Plan Failures. The PPC measures workflow reliability and helps identify reasons for plan failure so they can be acted upon (Ballard and Howell 1998). The LPS focuses on what must be done; therefore, it is essential to track completed work and compare it with the initial plan, to improve the planning process. PPC is calculated as the ratio of work performed to work planned. The use of PPC as a control measure may also increase the estimation accuracy of the duration of future planned work (Bhaidani et al. 2016, Ballard 2000). PPC is the most commonly implemented components of the LPS (Daniel et al. 2015).

\section{Maintenance}

Maintenance is "an activity aiming to maintain something in good working order, prevent operational disturbance and/or uphold a given technical standard" (RailNetEurope 2017). The two main maintenance types are preventive maintenance and corrective maintenance. In the former, measures are taken after an item's failure, while the latter is undertaken regularly to reduce the probability of an item's failure. Corrective maintenance in the case of failure tends to cost much more than preventive maintenance (Yile et al. 2008, Mostafa et al. 2015).

A significant number of track work activities require shutting down the railway track so that staff can carry out the measures. Maintenance planning processes are regulated by common European Union guidelines and requirements relating to how long in advance shutdowns must be notified, for operators - and, thus, travellers - to have the opportunity to adapt to the conditions with as little negative impact as possible (RailNetEurope 2017, Directive 2012/34/EU).

The concept of lean maintenance was defined by Smith (2004); later, Hammadi and Herrou (2018) described the concept as "a wise adaptation of lean alternatives to manage maintenance sources, their interactions and projects to make the maintenance and its related processes lean." The goal is to minimize the cost of maintenance activities by efficient planning and by illuminating the risks of an unscheduled breakdown. Therefore, the core of lean maintenance is well-planned, condition-based preventive maintenance.

The concept of lean maintenance refers to waste as inefficiently planned maintenance or maintenance that does not improve the infrastructure condition to ensure proper functioning (Olofsson 2019). Mostafa et al. (2015) described eight wastes as (1) unproductive maintenance, (2) waiting for maintenance resources, (3) centralised maintenance, (4) poor inventory management, (5) unnecessary motion, (6) poor maintenance, (7) ineffective data management and (8) under-utilisation of resources. Olofsson (2019) emphasised that lean maintenance differs from lean manufacturing by focusing mainly on the planning stage. Scheduling and performing several maintenance activities simultaneously reduces waste and makes the process cost- and time-efficient.

\section{METHOD}

The data collected for this study consist of scientific literature, interviews, documents and track work data from Trafikverket's database. The literature search focuses on lean principles and railway management. Internal regulations and recommendations related to contactor performance and planning processes were retrieved from Trafikverket's internal database. We also reviewed reports written by Trafikverket and external reports. 
To investigate a subjective perception of the maintenance planning process, the semistructured interviews with maintenance managers, representing different maintenance divisions in Sweden, were performed. The interviewees are the project managers from similar projects, with similar budgets, and timeframes. Twelve project managers from the client Trafikverket and ten site managers from the contractor companies were asked the same questions related to management principles (Table 1).

Table 1: Interview guide project managers and site managers

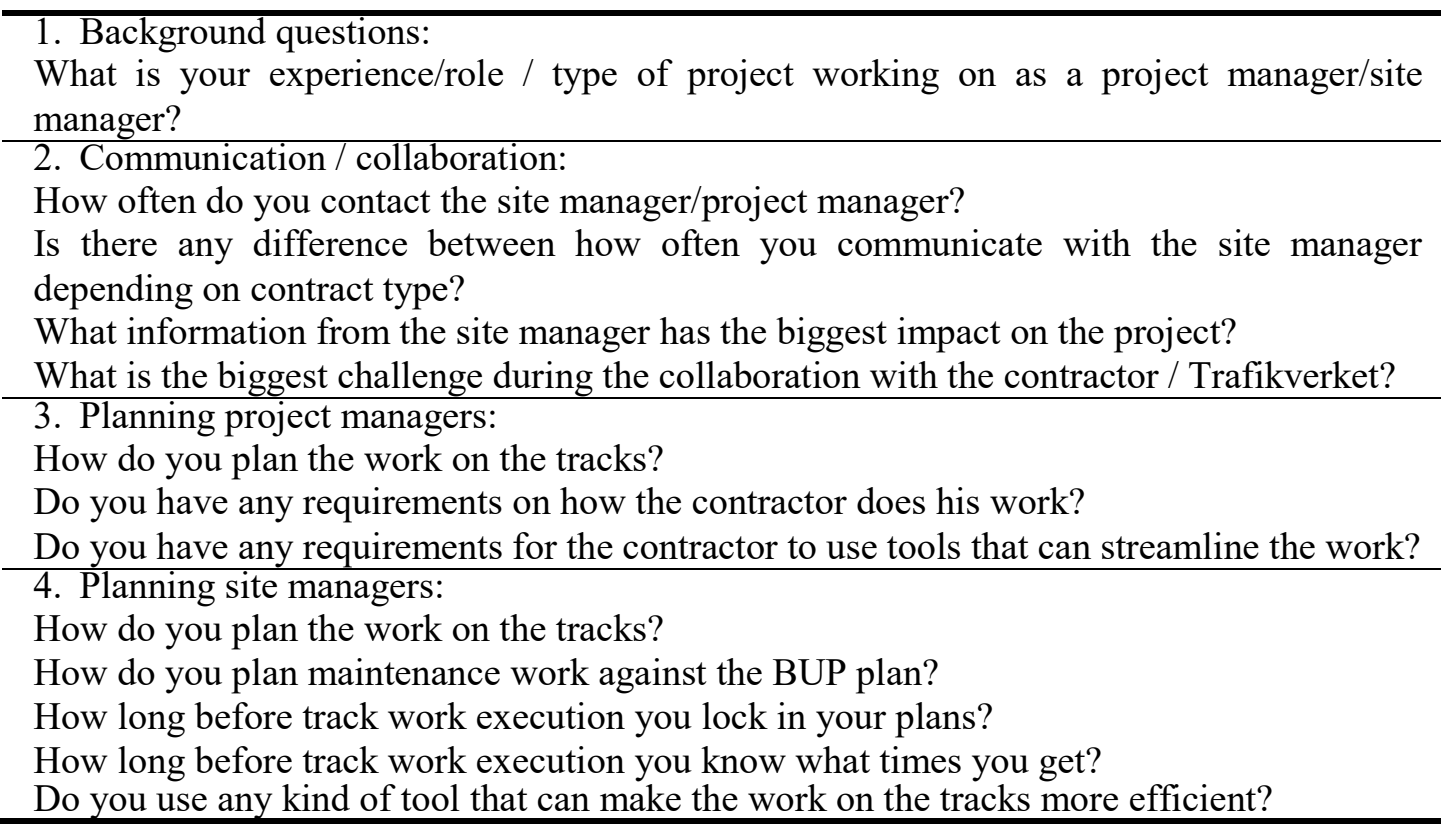

Percentage Plan Completed (PPC) analysis was performed to investigate if PPC can be a relevant measure and data availability for calculating PPC in this type of activity. Two datasets about the planned and used possession time for performing a certain activity, obtained from Trafikverket, were combined. The data sources were two different software used for planning (TrainPlan) and the control of work performed (LUPP). TrainPlan, contains records of all planned possessions on the track, applied by the contractor, while LUPP contains statistical data about actual work performed (BAR data). The data is selected from one region (southern Sweden) for one month (April 2019) due to its availability. We investigate the possessions booked for all types of track works, which create certain capacity restrictions for the running traffic, performed by four major maintenance companies operating in that area. The companies were anonymized.

\section{RESULTS}

This chapter starts with a discussion of the maintenance planning process. It continues with interview results, where we discuss knowledge exchange, performance indicators, planning complexity, and the possibility for lean principles adaptation. Then we present the test of PPC calculation utilizing data available at Trafikverket.

\section{Planning Process}

Planning for maintenance can begin several years before it must be carried out. The Network Statement (JNB), published annually by Trafikverket, describes the conditions that exist for running traffic on the tracks during the coming train schedule and forms the 
basis for the continued planning of track work (Honauer and Ödeen 2017, Lidén 2016, SOU 2015). The JNB includes planned major rail works (PSB), which are activities that have a great impact on traffic and are announced 1.5 years before the timetable is valid. The track work plan (BAP) describes when and where tracks are reserved for traffic (Trafikverket 2015). Maintenance must be planned for hours when there is less traffic on the tracks or when there is available time in the established maintenance windows (Gruhs 2015). When the BAP comes into effect, all track works for the upcoming year are established and coordinated with the traffic (Figure 1). All possible adjustments that are preferable from a production point of view, as well as entirely new works, are documented in the BUP, which is updated every week and contains a detailed description of the capacity needs (Trafikverket 2015; SOU 2015).

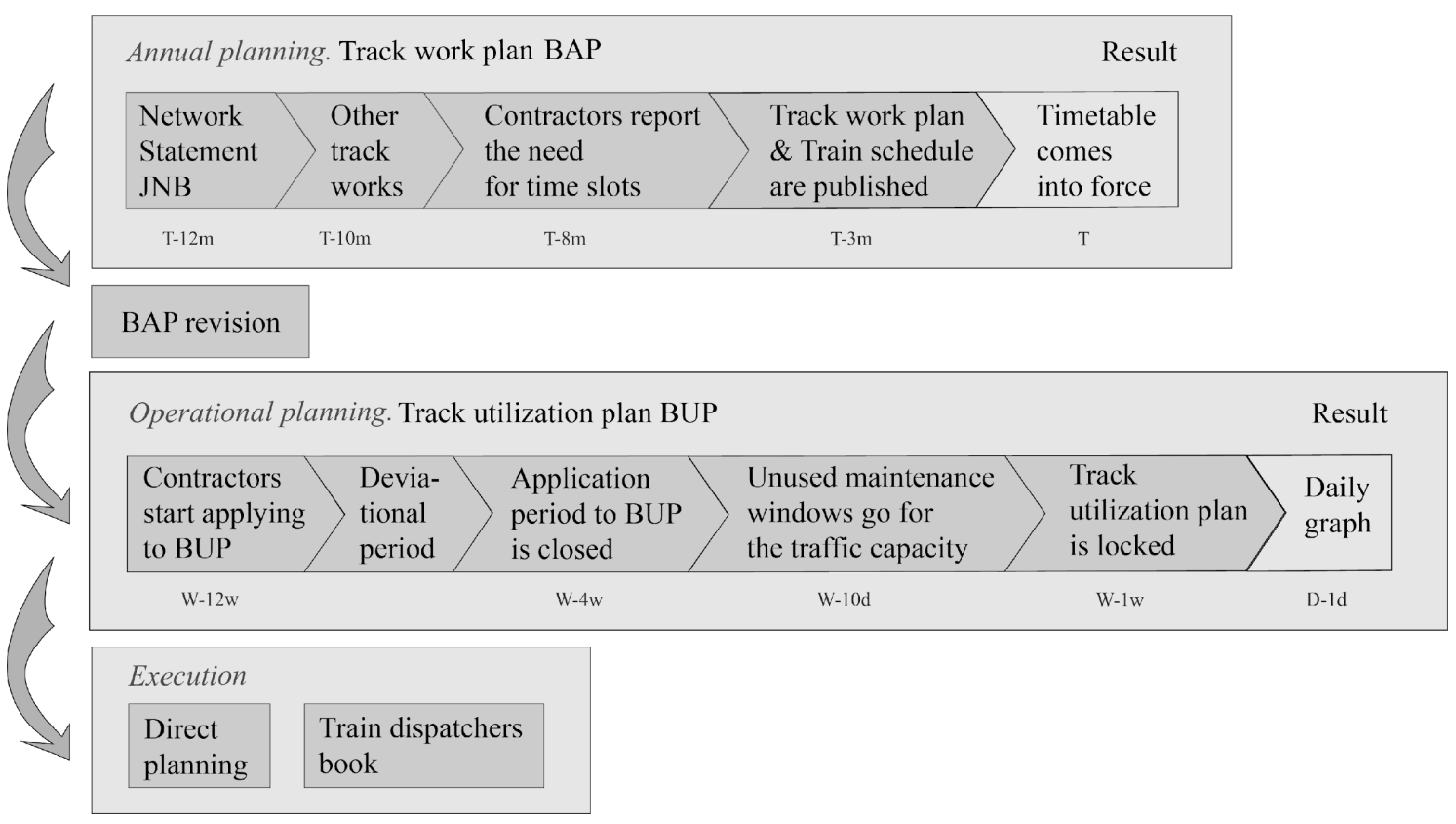

Figure 1: Maintenance planning process

Four weeks before the production week $(\mathrm{W}-4 \mathrm{w})$ is the final date for application times, including ready-made work plans and documents concerning security (Lidén and Joborn 2016). Higgins (1998), Lake et al. (2000, 2002), and Lake and Ferreira (2002) debated the complications of the weekly scheduling process at the last stages before the performance of track work. Contractors must apply for possessions in advance, before they are actually able to enter the stage of detailed process planning. This means they must guess, based on experience, how long each of their planned activities may take.

The day before production day (D-1d), all required documents - such as time-out descriptions (e.g., safety and contact information) and daily graphs - are created and submitted to the traffic control centres that handle train clearance. On production day, dispatchers can plan unplanned times via a manual procedure (Lidén and Joborn 2016).

The interviews reveal issues that potentially may affect the maintenance planning process and the quality of contractor's performance. For example, a challenge facing knowledge transfer after signing a new maintenance contract: experienced personnel usually leave their companies when the contract time is over and tend to avoid sharing knowledge with new workers. The same problem has been discussed and interpreted as a lack of collaboration and improvement culture by Farmer (2016). 
Some project managers at Trafikverket argued that contractors have poor skills in planning a long time in advance. According to planning regulations, works that are anticipated to take longer than fifteen minutes or that do not have an emergency case must be applied to the BUP no later than four weeks before execution. However, the interviews revealed that some contractors lock their plans less than four weeks before execution.

The interviews showed that site managers do not get enough possessions after the application process to perform preventive maintenance. The inability to perform preventive maintenance does not benefit the railway system in Sweden and ineffective from the lean maintenance perspective.

The performance measures used by Trafikverket to evaluate contractors are the experience index and maintenance index. The experience index is a subjective measurement of satisfaction in the collaboration between Trafikverket and the contractor, estimated by an independent external company. The maintenance index is used to measure the contractor's work efficiency, and it comprises multiple-input data (e.g., information about delays in the traffic, delays in the maintenance and infrastructure failures). According to the interviewees, these indices can vary from project to project. They can evaluate, for example, the number of infrastructure failures divided by the time taken to solve the failures. Other measurements can be the influence of the maintenance works on traffic or the time spent by the contractor to reach the worksite. These indices can also serve as a basis for fines estimation, which is usually done by project managers. The opinion of the interviewed contractors about fairness in the usage of these measurement indices was ambiguous; some said that these measurements do not have an influence on the performance quality, while others stated the importance of these measurements for workflow improvement.

The interviewees held various opinions about the implementation of lean principles and other planning techniques. While project managers at Trafikverket stated that there are no requirements for contractors to use any specific techniques or strategies at the operational stage, some contractors mentioned the use of lean principles in their practices, such as $5 \mathrm{~S}$ or the late locking of plans. However, there is a general lack of knowledge about lean principles among contractors, which creates complications in its adoption.

\section{PPC}

Possession time booked by maintenance contractor companies is costly, as it blocks trains from operating on the track. If contractors over- or underestimate their production time, it can result in maintenance-related waste. To test if PPC can be a relevant measure, we investigated if there was available data for calculating PPC.

The four major maintenance companies performing track works in southern Sweden during April 2019 were selected for the study (companies A, B, C and D). The data evaluated were: the time on the track applied for in the BUP document, the used time on the track and the time recorded in the BAR data. These data were combined and filtered down to the works that were performed by companies. The PPC was calculated as a percentage of time used by the contractor as a ratio of the total amount of possession time applied for in the BUP. The fluctuation between the announced time and actual contractor time was considered here as waste.

Figure 2 shows the PPC of all four studied companies. All the companies used more than $50 \%$ of their requested possession time. Company A had the highest PPC, as only $6 \%$ of the requested time was not used. Company $\mathrm{C}$ underestimated the time needed for 
performing maintenance when applying for possession time in the BUP, which resulted in the additional use of $24 \%$ of the possession time.

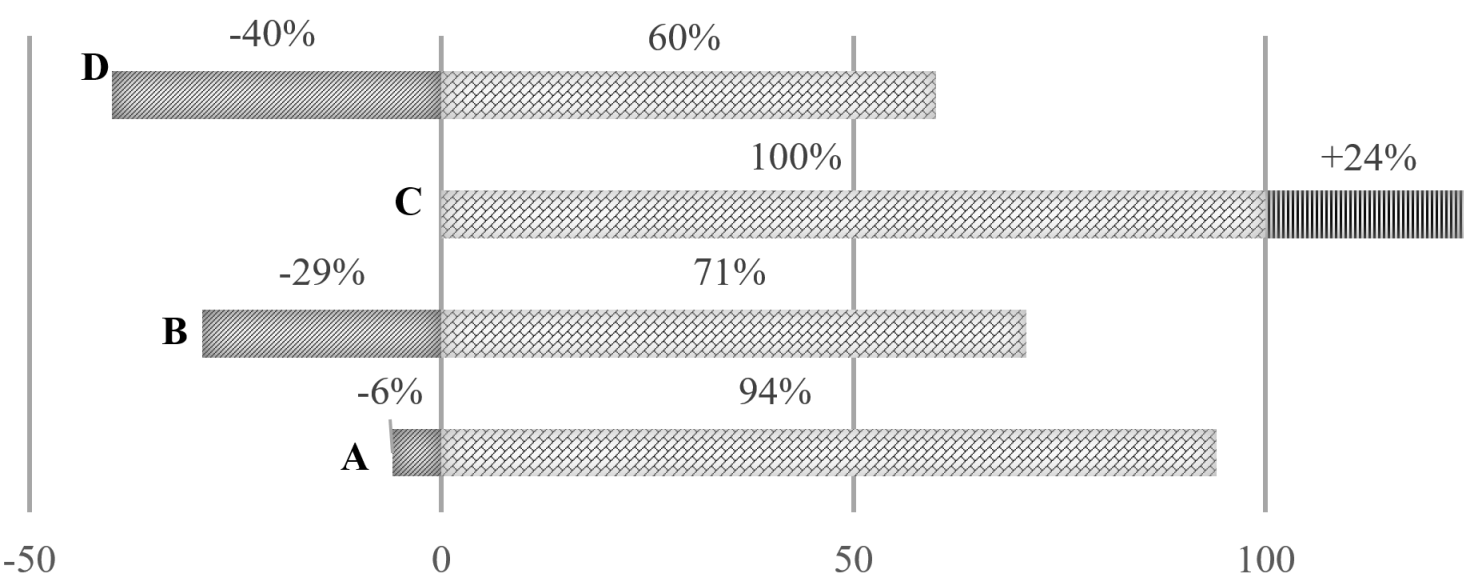

$\%$ time not used \% used possesions $\quad$ Iㅔ \% over used

Figure 2: PPC analysis (as a percent of used possessions)

\section{DISCUSSION}

In the following, we analyse maintenance planning in a lean construction perspective. The purpose is to compare observed practice with selected lean principles, in order to identify potential improvement.

It is not common practice to use lean construction principles for railway maintenance planning in Sweden. Trafikverket as a client and its contractors do not have enough knowledge about lean, and therefore, establishing changes to their work routine based on lean principles may face some barriers. Porwal et al. (2010) determined same challenges related to LPS implementation as inexperience, resistance to change and lack of training. Demirkesen et al. (2019) categorised barriers that can lead to the poor implementation of lean philosophy: political, economic, workforce, cultural, managerial, communication and technical barriers. The barriers identified in this study were a lack of knowledge about lean principles, employee resistance to change, inefficiency in source planning, lack of knowledge sharing and lack of trust. Such barriers were classified by Sarhan and Fox (2013) as "culture and human attitudinal issues" factors. They revealed a "lack of adequate lean awareness and understanding" as the most significant barrier to implementation of lean construction, based on 140 practitioners' opinions in the UK construction industry.

The barriers, revealed in the interview with contractors and client project managers, can be significantly reduced. For example, the lack of adequate lean awareness and understanding can be addressed by providing seminars and training to educate crew about lean principles and how to adopt lean principles into the workflow. Daniel (2017) provided a detailed description of step actions that could be taken at the project level in order to provide a smooth LPS application. The approach includes developing an effective strategy, which could potentially be done by Trafikverket in its role as a client. New innovative strategies need to be supported by top management (Sarhan and Fox 2013).

Table 2 shows the similarity of the LPS and management practices at Trafikverket. 
Table 2: Comparison of the LPS and planning at Trafikverket

\begin{tabular}{|c|c|c|}
\hline Last Planner ${ }^{\circledR}$ principles & $\begin{array}{c}\text { Operational planning principles } \\
\text { (BAP / BUP) }\end{array}$ & Improvement potential \\
\hline $\begin{array}{l}\text { Plan in greater detail as you } \\
\text { get closer to doing the work. }\end{array}$ & $\begin{array}{l}\text { The contractors are responsible to plan in } \\
\text { a great level of detail as it gets closer to } \\
\text { the execution stage. The application for } \\
\text { possessions (12-4 weeks before } \\
\text { execution). }\end{array}$ & $\begin{array}{l}\text { Make the planning more } \\
\text { detailed at Trafikverket. } \\
\text { Involve contractors in the } \\
\text { design process. }\end{array}$ \\
\hline $\begin{array}{l}\text { Produce plans } \\
\text { collaboratively with those } \\
\text { who will do the work. }\end{array}$ & $\begin{array}{c}\text { The contractor is fully responsible for } \\
\text { planning at the operational stage. } \\
\text { Depending on the contract type, both } \\
\text { parties could be involved at the design } \\
\text { stage. }\end{array}$ & $\begin{array}{l}\text { Improve collaboration } \\
\text { quality, data exchange, } \\
\text { and understanding of both } \\
\text { parties' needs. }\end{array}$ \\
\hline $\begin{array}{c}\text { Reveal and remove } \\
\text { constraints on planned tasks } \\
\text { as a team. }\end{array}$ & $\begin{array}{l}\text { More of ad-hoc principles in the } \\
\text { contractor's planning. }\end{array}$ & $\begin{array}{l}\text { Set regulations for } \\
\text { processes management at } \\
\text { contractors. Encourage } \\
\text { development. }\end{array}$ \\
\hline $\begin{array}{l}\text { Make and secure reliable } \\
\text { promises. }\end{array}$ & $\begin{array}{l}\text { There is a lack of owners' trust in } \\
\text { contractors. Contractors do not always } \\
\text { keep deadlines. }\end{array}$ & $\begin{array}{l}\text { Promote efficient time } \\
\text { management and } \\
\text { possession planning. }\end{array}$ \\
\hline $\begin{array}{l}\text { Measure promises kept } \\
\text { (planning capabilities, PPC) } \\
\text { in order to improve by } \\
\text { learning from variance } \\
\text { (workflow disruptions). }\end{array}$ & $\begin{array}{c}\text { Trafikverket regularly inspects } \\
\text { maintenance quality performed by } \\
\text { contractors and controls the possession } \\
\text { usage. }\end{array}$ & $\begin{array}{l}\text { Provide automated tools } \\
\text { for measuring the } \\
\text { contractor`s performance. } \\
\text { Assure learning from } \\
\text { experience. }\end{array}$ \\
\hline $\begin{array}{l}\text { Continuously improve as a } \\
\text { team, remove waste and } \\
\text { adjust performance based on } \\
\text { what has been learned to } \\
\text { optimise workflows. }\end{array}$ & $\begin{array}{l}\text { Meetings and panel discussions are held } \\
\text { in Trafikverket, and the responsible } \\
\text { project leaders are conducting team } \\
\text { performance analysis occasionally. }\end{array}$ & $\begin{array}{l}\text { Remove waste. Focus on } \\
\text { preventive maintenance. } \\
\text { Follow up on the quality } \\
\text { of the planning. }\end{array}$ \\
\hline
\end{tabular}

Several maintenance operations can be standardised to reduce different types of waste. The concept of "scheduling out maintenance" can be adopted in a lean maintenance environment to maximise the efficiency of operations and maintenance personnel. The estimation of work duration must be accurate, and delays must be avoided (Heisler 2003).

The concept of gradually increasing the level of detail from BAP to BUP shares several elements with LPS. BAP plan contains few details and specifications, while BUP is a more detailed plan created closer to the execution stage (see Figure 1).

Lean thinking in project management means postponing decisions until the last responsible moment to allow the possibility of identifying and studying alternatives. Waiting until the last responsible moment to make a decision makes contractors' planning processes more efficient from a production point of view. Ruled by this principle, contractors are expected to apply for possession time as close to the execution stage as possible. Therefore, the detailed planning conducted by Trafikverket could be optimised by introducing a shorter (e.g., weekly) period in which applications for work could be conducted. While this would let the contractor perform necessary maintenance at the most suitable times, it does have some disadvantages for the whole timetabling process.

Figure 3 illustrates the similarities between planning for railway maintenance and LPS project planning levels. Initial planning, presented in the figure as "master scheduling" and "phase scheduling," produces the initial requirement for the contractor in terms of 
budget, level of responsibility and predetermined time in the timetable for carrying out the maintenance activities. At this stage, Trafikverket as a client is responsible to prioritise the works that should be done. Look ahead planning includes the planned maintenance activities within a one-year period. All planned works that affect traffic are, as mentioned before, documented in the BAP document, and the timetable for the upcoming year is published. At this stage, timetable planners and Trafikverket still predetermine for contractors the works that can be done. Contractors then conduct infrastructure inspection to prioritise the works that can be done within the predetermined timeframes (i.e., possessions). A weekly plan is the result of short-term planning before the execution stage, and it can be divided into two aspects: (1) the detailed plan, which is the BUP document, in which all the planned maintenance activities are documented, and (2) the operational plan, which is created by contractors, as they must perform crew and equipment planning.

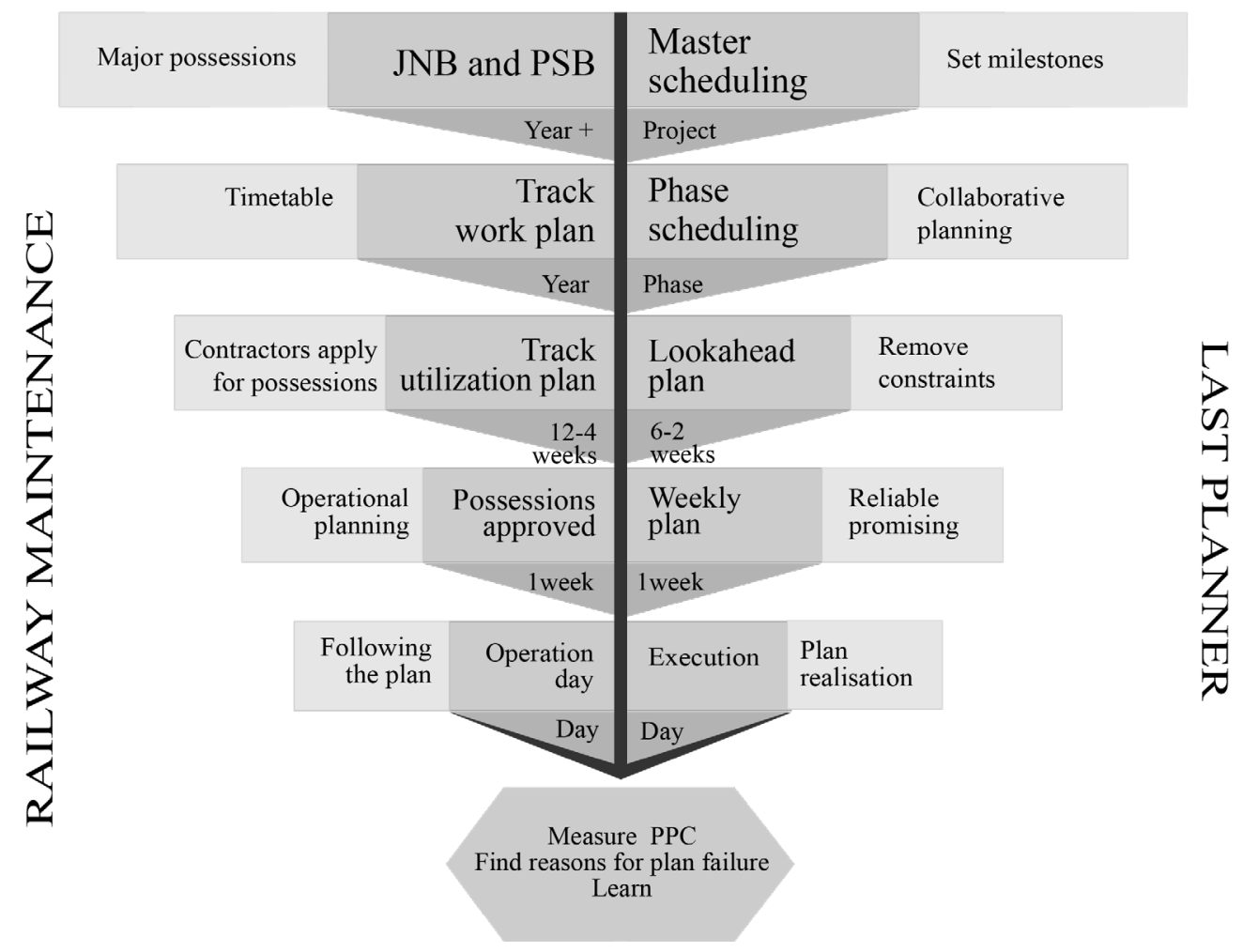

Figure 3: Planning process for railway maintenance versus the LPS

In management, it is often said that what cannot be measured cannot be improved (Daniel 2017). At the final stage of maintenance works, execution contractors must follow the plan and use the possession previously applied for in the BUP document. We did a test of the possibilities to calculate PPC of maintenance execution. This was done as a preparation for a possible future recommendation to adopt the PPC technique for measuring maintenance planning effectiveness. The test indicates that PPC evaluation technique can be used by Trafikverket as a contractor performance indicator. Through the project duration, PPC must be tracked consistently, analysed, and discussed at internal meetings to evaluate each project's effectiveness. 


\section{CONCLUSION}

This study focused on the possibilities of using lean principles in the Swedish railway maintenance market. The study is, as far as we know, the first of its kind. A comparison of every stage of the maintenance planning process with the stages used in the LPS is presented. Through such a comparison analysis, it was possible to distinguish certain actions that could be taken to improve the current status of each stage.

The study demonstrated how Last Planner ${ }^{\circledR}$ principles could improve effectiveness in maintenance processes. The study presented an example of how the available data at Trafikverket can be used to analyse the performance of contractors. We tested PPC calculation and found that data is available for such calculations. We do not recommend to use PPC in isolation, but as a part of larger lean construction implementation.

Although the study showed that it is possible to improve operational planning processes by applying lean principles, some barriers to its implementation do exist. The main problem is a lack of knowledge about lean principles on the contractors' side. The adoption of lean principles requires a lot of effort from governmental clients as well as contractor companies. Such an implementation could be supported by introducing incentives to encourage the use of lean, an initiative that should come from the client.

\section{ACKNOWLEDGMENTS}

We would like to express gratitude to Robin Stenberg and Mikael Thorsén, who contributed to this work with their ideas and inspiration. The 22 interviews with engineers in the field of maintenance were performed by Robin Stenberg for his master's thesis, "Communication and Contracts in Maintenance Operations" (Stenberg 2019).

\section{REFERENCES}

Aziz, R.F. and Hafez, S.M. 2013. "Applying lean thinking in construction and performance improvement." Alexandria Engineering Journal, 52(4):679-95.

Babalola, O., Ibem, E.O., and Ezema, I.E. 2019. "Implementation of lean practices in the construction industry: A systematic review." Building and Environment. 148:34-43.

Ballard, G. 2000. "Lean Project Delivery System." Lean Construction Institute. White paper, 8:1-6.

Ballard, G. and Howell, G. 1998. "Shielding production: essential step in production control." Journal of Construction Engineering and Management, 124(1): 11-17.

Ballard, G. and Tommelein, I.D. 2016. Current Process Benchmark for the Last Planner ${ }^{\circledR}$ System. Available at p2sl.berkeley.edu

Daniel, E.I. and Pasquire, C. 2017. "Last Planner ${ }^{\circledR}$ System Path Clearing Approach (LPSPCA): an approach to guide clients, main contractors, and subcontractors in the implementation of the LPS." Nottingham: Nottingham Trent University: Publications.

Daniel, E.I., Pasquire, C., and Dickens, G. 2015. "Exploring the implementation of the Last Planner ${ }^{\circledR}$ System through IGLC community: twenty-one years of experience." Proc. 23rd Ann. Conf. Int. Group for Lean Constr., Perth, Australia, pp. 153-162.

Demirkesen, S., Wachter, N., Oprach, S., Haghsheno, S. 2019. "Identifying barriers in lean implementation in the construction industry." Proc. 27th Ann. Conf. Int. Group for Lean Constr., Pasquire, C. and Hamzeh, F.R. (eds.), Dublin, Ireland, 157-168.

Directive 2012/34/EU of the European Parliament and of the Council of 21 November 2012. Establishing a single European railway area. Accessed: October 10, 2019. http://data.europa.eu/eli/dir/2012/34/oj 
Dirnberger, J. and Barkan, C. 2007. "Lean railroading for improving railroad classification terminal performance: Bottleneck Management Methods." Transportation Research Record, 1995(1): 52-61.

Farmer, M. 2016. "Modernise or Die: Time to decide the industry's future - The Farmer Review of the UK Construction Labour Model." London: Construction Leadership Council.

Forsgren, M., Aronsson, M., and Gestrelius, S. 2013. "Maintaining tracks and traffic flow at the same time." Journal of Rail Transport Planning \& Management (3):111-123.

Globerson, S. and Zwikael, O. 2002. "The Impact of the Project Manager on Project Management Planning Processes.” Project Management Journal, 33(3), 58-64.

Gruhs, P. 2015. "Alternativ för framtida organisering av järnvägsunderhållet." [Alternatives for future organization of railway maintenance]. [In Swedish]. Trafikverket.

Hammadi, S. and Herrou, B. 2018. "Lean maintenance logistics management: The key to green and sustainable performance." Proc. 4th Int. Conf. on Logistics Operations Management (GOL) Le Havre, France, 1-6.

Heisler, R. 2003. "Planning and scheduling in a lean maintenance environment." Accessed December 20, 2003:2014.

Heravi, A., Coffey, V., and Trigunarsyah, B. 2015. "Evaluating the level of stakeholder involvement during the project planning processes of building projects." International Journal of Project Management, 33(5): 985-997.

Higgins, A. 1998. "Scheduling of railway track maintenance activities and crews." The Journal of the Operational Research Society, 49, 1026. doi:10.2307/3010526.

Honauer, U. and Ödeen, S. 2017. "Underhållsplan 2017-2020." [Maintenance plan] [In Swedish]. Report, Trafikverket.

Koerckell, A. and Ballard, G. 2005. "Return on investment in construction innovationa lean construction case study." Proc. 13th Ann. Conf. Int. Group for Lean Constr., Sydney, Australia.

Koskela, L. 1999. "Management of production in construction: a theoretical view." In: Proc. 7th Ann. Conf. Int. Group for Lean Constr., Berkeley, California, USA.

Lake, M. and Ferreira, L.J. 2002. "Minimising the conflict between rail operations and infrastructure maintenance." Transportation and traffic theory, 15, 63-74.

Lake, M., Ferreira, L., and Kozan, E. 2002. "Heuristic techniques for scheduling railway track maintenance." Int. Series in Operations Res. and Manage. Science, 177-188.

Lake, M., Ferreira, L., and Murray, M. 2000. "Minimising costs in scheduling railway track maintenance." Proc. 7th Int. Conf. on Computers in Railways, WIT Press, pp. 895-902.

Last Planner ${ }^{\circledR}$ System Business Process Standard and Guidelines. 2016. Accessed: October 20, 2019. https://www.leanconstruction.org/media/docs/chapterpdf/israel/ Last_Planner_System_Business_Process_Standard_and_Guidelines.pdf

Lidén, T. 2016. "Towards concurrent planning of railway maintenance and train services." Linköping University Electronic Press, Vol. 1746.

Lidén, T. 2018. Concurrent planning of railway maintenance windows and train services. (Doctoral dissertation). Linköping: Linköping University Electronic Press

Lidén, T. and Joborn, M. 2016. "Dimensioning windows for railway infrastructure maintenance: cost efficiency versus traffic impact." Journal of Rail Transport Planning \& Management, 6(1):32-47. 
Mostafa, S., Dumrak, J., Lee, S-H., and Chileshe, N. 2015. "Lean thinking for a maintenance process." Production \& Manufacturing Research: An Open Access Journal, 3(1): 236-272.

Nikitinas, V. and Dailydka, S. 2016. "The Models of Management of Railway Companies in the European Union: Holding, the German Experience." Procedia Engineering, 134:80-88.

Olofsson, O. 2019. "Lean maintenance - lean manufacturing needs reliable machines." Accessed November 19, 2019, https://world-class-manufacturing.com/tpm/ leanmaintenance.html

Porwal, V., Fernandez-Solis, J., Lavy, S., and Rybkowski, Z. 2010. "Last planner system implementation challenges." Proc. 18th Annual Conf. Int. Group for Lean Constr., Technion, Haifa, Israel, 548-556.

Radnor, Z. 2006. "Evaluation of the lean approach to business management and its use in the public sector." Scottish Executive Social Research. Warwick Business School.

RailNetEurope 2017. "RailNetEurope - glossary of terms related to network statements." RailNetEurope (ed.), 9.0.

Salem, O., Solomon, J., Genaidy, A., and Luegring, M. 2005. "Site Implementation and Assessment of Lean Construction Techniques." Lean Construction J., 2(2):1-21

Sarhan, S.H. and Fox, A. 2013. "Barriers to implementing lean construction in the UK construction industry." The Built \& Human Environment Review, 2013(6).

Smith, R. 2004. "What is lean maintenance?" Maintenance Technology, 17:15-21.

SOU 2015:42 2015. "Koll på anläggningen." [Keep track of the facility]. [In Swedish]. Stockholm, Sweden.

Stenberg, R. 2019. "Communication and Contracts in Maintenance Operations." Master's thesis, Norwegian University of Science and Technology, Trondheim, Norway.

Trafikverket 2015. "Banarbetstider för underhåll av järnvägsanläggningen" [Railway working hours for maintenance of the railway system]. [In Swedish]. Physical copy obtained from Trafikverket.

Trafikverket 2018. "Förslag till nationell plan för transportsystemet 2018-2029." [Proposed national plan for the transport system 2018-2029]. [In Swedish].

Wolbers, M., Evans, R.J.E, Holmes, M., Pasquire, C.L., and Price, A.D.F. 2005. "Construction management and lean thinking in highways maintenance." Proc. $28^{\text {th }}$ Annual ARCOM Conference. 3-5 September 2012, Edinburg, Texas, USA.

Yile, L., Hang, X.X., and Lei, Z. 2008. "Lean Maintenance Framework and Its Application in Clutch Maintenance," Proc. Int. Conf. on Information Management, Innovation Management and Industrial Engineering, Taipei, Taiwan. pp. 230-232.

Zoeteman, A. 2006. "Asset maintenance management: State of the art in the European railways." International Journal of Critical Infrastructures, 2(2):171-186

Zwas, A. 2006. "Lean manufacturing techniques in bus and rail maintenance: Study at Chicago transit authority in Illinois." Transportation Research Record, Washington, DC., USA, 1986(1):54-58. 